\title{
Managing Campus Energy: Compromising between Rapid Needs and Environmental Requirement
}

\author{
Ambariyanto Ambariyanto ${ }^{1,2, *}$, Yos J. Utama ${ }^{3}$, and Purwanto ${ }^{4}$, \\ ${ }^{1}$ Faculty of Fisheries and Marine Science, Diponegoro University, 50275 Jl. Prof.Soedarto SH, Tembalang Campus, Semarang, \\ Indonesia \\ ${ }^{2}$ Coastal Disaster Rehabilitation and Mitigation Center (COREM), Integrated Laboratory, Diponegoro University, 50275 Jl. Prof. H. \\ Soedarto, SH, Tembalang, Semarang, Indonesia \\ ${ }^{3}$ Faculty of Law,Diponegoro University, $50275 \mathrm{Jl}$. Prof.Soedarto SH, Tembalang Campus, Semarang, Indonesia \\ ${ }^{4}$ School of Postgraduate Studies, Diponegoro University, 50275 Jl. Prof.Soedarto SH, Tembalang Campus, Semarang, Indonesia
}

\begin{abstract}
The utilization of energy, especially electric ity at Diponegoro University campus continues to increase in line with the development of the university. This increase has a direct impact on the increased costs to be paid by the university. Some of the causes of increased utilization of electrical energy is the construction of new buildings to meet the needs, increased learning activities and education, research activities in the laboratory, and various other activities. On the other hand, the increase of energy utilization is considered not good from the environment point of view, especially the utilization of electrical energy coming from non sustainable resources. Efforts to compromise on both are to develop polic ies in developing environmentally friendly buildings, efficiency in utilization of electrical energy, and development of sustainable energy sources.
\end{abstract}

\section{Introduction}

Increased energy demand is now become an international issue $[1,2,3]$. The utilization of energy especially electricity continues to increase sharply in various sectors, both government, private and public (urban) sector, and in line with economic growth [4,5]. Increased utilization of energy is in line with the needs of the development of modern society around the world. Various fields and activities by all sectors, continue to move up, both in order to improve the ability, capacity and achievements and targets, including within the university campus, all require energy.

The development of campus around the world both in terms of technology and educational process to become a modern campus, also requires electrical energy continues to increase. This can not be avoided because of high energy demands of the modern campus development [6]. But on the other hand, the campus is also one place to be able to develop technology for new power plants through their research and development activities.

The issue of increasing the utilization of electrical energy is considered contrary to environmental principles, especially in relation to emission [7]. This is particularly aimed at electrical energy sourced from non-sustainable natural resources, such as oil resources, coal, and so on [8]. So that the increased use of electricity as it is considered to also encourage environmental damage.

A further impact is the emergence of renewable energy development issues that are growing all over the world. Various efforts continue to be done to produce sustainable energy. Increased utilization of science and technology also requires high electrical energy, but on the other hand with the advancement of science and technology are also able to efficiently utilize the energy, as well as generate new generating technologies. Currently, many power plants are derived from sustainable natural resources [9], among others, by utilizing wind, sunlight, currents or waves, etc.

This condition is also faced by various universities in Indonesia, including Diponegoro University (Undip) in Semarang. Increased utilization of electrical energy continues to increase in line with the policy of Undip to accelerate in achieving the vision of becoming a research university [10]. This condition has a direct impact with the increased cost of electricity that must be provided by the university. In addition, university management is also fully aware if this increase in the utilization of electrical energy is in conflict with environmental principles and sustainable university [11]. This brief paper will convey the compromise policy undertaken by Undip management in addressing the problem of increasing the utilization of electrical energy and efforts to become a sustainable environmental campus.

*Corresponding author: ambariyanto.undip@gmail.com 


\section{Causes of increased utilization of electrical energy}

Increased utilization of electricity at Diponegoro University is mainly due to the acceleration programs to achieve the Undip vision. Educational and teaching activities, and research are the main causes, in addition to the construction of new buildings and rooms. Besides that, various other extracurricular activities run by faculty with students also influence the increase of electric energy usage. In more detail, the causes of increased utilization of electrical energy are as follows:

\subsection{Development of new buildings}

Construction of new buildings and rooms continues to be done at Diponegoro University because of the need due to the establishment of new units and because the old building is no longer feasible for certain faculties. Besides the effort to develop an ideal class, where the number of students is not too large in one class, also need new rooms. Some new buildings to meet these needs include for a newly formed vocational school, as well as new study programs, and construction of a new building for Psychology and other faculties.

By increasing the economics capabilities of lecturers, and employees, many of them use cars to work. This is worsen by the number of students who also use the car to campus. The problem is that some of them park their cars on the street because the parking space is not enough. This causes the disruption of traffic within the campus. To overcome the problem Undip provides a new parking building because the old parking lot is not able to accommodate the increasing number of cars.

Dormitory student demand continues to increase, especially by new students who come from outside the city of Semarang. To fulfill this high demand, nowadays Undip is building a new student dormitory that will accommodate many students. One of the newly completed buildings is the ICT II building which will serve as a training place as well as other commercial activities.

The existence of these new buildings requires electrical energy both for the construction process and for the operation of the building, for example for lighting, air conditioning, and for other needs. This causes an increase in the need for electrical energy at Diponegoro University.

\subsection{Learning and education activities}

One indicator of the success of a higher education is determined by the quality and competence of its graduates, especially after acting in the community and workplace. All universities continue to work to improve the quality of graduates in line with the development of science and technology.

Improving the quality and competence of graduates also continues to be done Diponegoro University through various programs, such as training activities, tutorials, discussion forums and so forth. These activities are also linked to efforts to accelerate the achievement of Undip's vision into a research university.

Education and learning activities are also increasing in line with the newly established study programs. For example, the opening of Pharmacy and Dentistry courses, as well as other programs. In addition, with the development of science and technology, encourage the process of education and learning on existing courses also experienced an increase in both quantity and quality.

\subsection{Research activities}

Research is one of the main activities of the university that has a vision to become a research university. The success of the research activities is not only determined by adequate human resources, but also the availability of laboratories and various other equipment and facilities [12]. Important policies ofDiponegoro University is to provide facilities and infrastructure to accelerate research activities for students and lecturers.

The year 2018 is the "laboratory year" in Undip. A special program is undertaken to address the problem of adequate laboratory availability for research that not only generates articles for international journals but is also expected to produce innovation products ready for commercialization. In turn these commercial products can support the university's finances.

By increasing the availability of laboratories, the research activities in Undip also continue to increase both in quantity and quality. It is also supported by the policy of allowing students and lecturers to conduct research in the laboratory for 24 hours 7 days. So with the increasing amount of equipment in the laboratory and research activities led to an increase in electrical energy demand $[13,14]$.

\subsection{Other activities}

There are many other activities conducted at Diponegoro University in addition to education, research and community service which is the core activities of universities. Various activities are undertaken by the entire academic community of Undip, both students, lecturers, and other employees. These activities are in some ways related to educational processes or skills and capacity improvements, such as summer courses, seminars, trainings, or discussions. In addition, there are also other activities related to sports such as futsal, tennis, badminton, basketball and so on. Other activities related to artistic skills such as classical and modern dance, choir, band, and so on.

Other activities are also carried out by student activity units both at the university level and at the faculty and department level. These activities of course require electrical energy both for stadium lighting, lighting and air conditioning, and related toequipments usage. 


\section{Compromise policies}

Increased utilization of electric energy in Undip basically can be understood, because it is really needed, both for educational and research and other activities. On the other hand, Undip intends to develop sustainable university especially related to the application of environmentally friendly principles. Therefore, a policy compromise is required that minimizes the utilization of electricity at the same time encourages increased activity to achieve the university's vision. Some of the compromise policies are as follows:

\subsection{Environmental friendly buildings}

The construction of the building at Diponegoro University must meet environmental requirements and principles. Besides expected to have an artistic and functional design, the building must be built in accordance with the principle of environment, with one of the goals for the electricity needs to be minimal. There is a need an environmental assessment tools fof sustainable construction [15]. For example, the design of the building should be able to utilize sunlight for natural lighting in the building room, so it will not require lights during the day $[16,17]$. The use of translucent walls is encouraged in the construction of buildings to exploit and use the availability of sunlight outside the building.

On the other hand, given that Semarang which is in tropical climate there is a tendency of high temperatures in a closed room [18]. The high temperature in the room will affect the performance of students and lecturers. In general, this is overcome by providing an air conditioner to increase comfort [19]. Therefore, the design of the building should be able to provide arrangements regarding airflow in the form of ventilation so that the room will be relatively cool, and the use of air conditioning is also getting minimal.

\subsection{Efficiency energy utilization}

In general, people awareness in conserving electricity, somewhat is still need to be improved [20]. In the case of our university, the use of electricity in the campus of Undip during this time is "less regulated" so freely utilized by all units. As a result there are things that cause excessive use of electricity, such as lighting, air conditioning and so on, which is not limited. Many found the room air conditioner was not turned off at night even though the office or classroom was closed and nobody was working in the room. But for special rooms where there are facilities or research equipment, or there is ongoing research that requires air conditioning then it is understandable and allowed. Our awareness to turn off the air conditioner when the room is not in used is still very low.

In comparison, our awareness on the use of lighting in rooms is much better. Generally the room lights are turned off when the office is closed at night. However, since this has not yet taken place in all parts of the campus, there is still room with lights on at night even though no one works in it. So the policy is to encourage all people, students, lecturers and other staff to turn off the air conditioner and lighting the room if it is no longer needed. In addition, the duty officers are also given the responsibility to do so, when at night they perform the activities of unit or campus security monitoring. There is currently a study on the development of automation to turn off air conditioning and lighting the room if it is not needed. There is a need to establish energy consumption information system to improve the awareness of reducing energy usage $[21,22]$. Through these policies, it is expected that efficiency of electricity utilization will be applied throughout the campus area of Undip.

\subsection{Development of sustainable energy sources}

Policies on the sustainable use of energy sources began to be implemented at Diponegoro University. Currently electrical energy is still obtained from the office of PLN (State Electricity Company) owned by the government, and costs continue to increase in line with increased utilization of electricity. Another policy taken today is the more sustainable use of electricity.

Currently Undip is working with the Japanese to develop electricity with three alternative sources i.e. solar power, wind power and micro hydro [23, 24]. These three alternatives are under studied at their efficiency level if implemented on the Undip campus. One consideration is whether the use of this power source will be able to reduce the cost burden that has been paid to PLN. Even though until now has not been decided, but Undip policy is to increase the use of electricity more sustainable and more environmentally friendly.

\section{Conclusion}

The rapid increase of electricity utilization on the Diponegoro University campus is understandable, given the good development of Undip to become a research university. However, considering that the use of this energy is considered not in line with environmental policy, it is necessary to compromise the efficiency of electricity usage policies but also encourage various activities aimed at accelerating the achievement of Undip vision to become a research university.

\section{References}

1. Asif, M. and Muneer, T. Renewable and Sustainable Energy Reviews, 11.7: 13881413,(2007).

2. Pérez-lombard, L., Ortiz, J. and Pout, C. Energy and Buildings, 40.3: 394-398, (2008) 
3. Payne, J.E. Journal of Economic Studies, 37,1: 53-95, (2010).

4. Santamouris, M.Cartalis, C., Synnefa, A. andKolokotsa, D. Energy and Buildings, 98: 119124,(2015).

5. Yoo, S-H. Energy Policy, 33.12: 1627-1632, (2005).

6. Moreno-Muñoz, A.,Redel, M.D. and González, M. Power quality in high-tech campus: A case study. Proceedings of the Institution of Mechanical Engineers, Part A: Journal of Power and Energy, 220.3: 257-269,(2006).

7. Chan, W.W., and Lam, J.C. International Journal of Hospitality Management, 21.4: 381391,(2002).

8. Sims, R.E.H.,Rogner, H-H. and Gregory, K. Energy Policy,31,13: 1315-1326,(2003).

9. Ahmad, S. and Tahar, R.M. Renewable energy,63: 458-466,(2014).

10. Utama, Y.J. and Ambariyanto, A. Achieving Research University: Indonesian Case. In IOP Conference Series: Earth and Environmental Science,55, 1: 012072, (2017).

11. Utama, Y.J., Purwanto, Ambariyanto, A. Developing Environmentally Friendly Campus at Diponegoro University. Advanced Science Letters, 23(3): 2584-2585,(2017).

12. Tobin, K. School science and Mathematics,90.5: 403-418,(1990).
13. Salpanio, R.,Warsito, A. and Winardi, B. Transmisi, 9.2: 181-190. (2007).

14. Badruz zaman, JTET, 1.2: 50-59,(2012).

15. Ding, G.K. Journal of environmental management, 86(3):451-64, (2008).

16. Rosemann, A., Mossman, M. and Whitehead, L. Solar Energy, 82.4: 302-310, (2008).

17. Duguay, M.A. and Edgar, R.M. Applied Optics, 16.5: 1444-1446,(1977).

18. Hirunlabh, J., Kongduang, W., Namprakai, P. and Khedari, J. Renewable Energy, 18.1: 109-119, (1999).

19. Ostro, B., Rauch, S. Green,R. and Malig, B. American Journal of Epidemiology, 172.9: 10531061, (2010).

20. Mcmakin, A.H., Malone, E.L. and Lundgren, R.E. Environment and Behavior, 34.6: 848-863, (2002).

21. Ueno, T.,Sano, F., Saeki, O, and Tsuji, K. Applied Energy, 83.2: 166-183. (2006).

22. Vikhorev, K., Greenough, R. and Brown, N. Journal of Cleaner Production, 43: 103112,(2013).

23. Bakos, G.C. Applied Energy, 72.3: 599608,(2002).

24. Singh, G.K. A review. Energy, 53: 1-13, (2013). 